Kolaborasi : Jurnal Administrasi Publik, Desember 2017 Volume 3 Nomor 3

\title{
PERAN PEMERINTAH DALAM MENANGANI KONFLIK PEMUTUSAN HUBUNGAN KERJA KARYAWAN PT GUNUNG MAS DI KABUPATEN PANGKEP
}

\author{
Fatwal Fahrunnisa' ${ }^{1}$, Rosdianti Razak $^{2}$,Alimuddin Said ${ }^{3}$ \\ 1)Jurusan Ilmu Administrasi Negara Unismuh Makassar \\ 2)Jurusan Ilmu Administrasi Negara Unismuh Makassar \\ 3)Jurusan Ilmu Pemerintahan Unismuh Makassar
}

\begin{abstract}
The objective of this research is to know how the role of government in handle the termination of employment conflict at PT Gunung Mas Persada Jaya in Pangkep Regency and what were the supporting and inhibiting from government in doing their role. The type of the research is descriptive qualitative and the sample were eight informants, the technique of data collection were collected by interview the informant and observation. The result of research showed that the government in implementing the role as regulation, administrator and fasilitator has been realized well, because there was agreement between the employees and the company through Tripartit negotiations.
\end{abstract}

keywords : Government role, conflict, Termination of employment

\begin{abstract}
ABSTRAK
Adapun tujuan dari penelitian ini adalah untuk mengetahui bagaimana peran pemerintah dalam menangani konflik pemutusan hubungan kerja karyawan PT Gunung Mas Persada Jaya di Kabupaten Pangkep dan apa saja yang menjadi penunjang dan penghambat pemerintah dalam menjalankan perannya. Jenis penelitian ini adalah deskriptif kualitatif dengan informan sebanyak delapan orang, teknik pengumpulan data dikumpulkan dengan menggunakan instrument berupa wawancara terhadap informan dan observasi. Hasil penelitian menunjukkan bahwa pemerintah dalam menjalankan peranannya sebagai regulator, dinamisator dan fasilitator sudah terealisasi dengan baik, dilihat dari ditemukannya kesepakatan antara karyawan yang diPHK dengan pihak perusahaan melalui perundingan Tripartit.
\end{abstract}

Kata Kunci: peran pemerintah, konflik, pemutusan hubungan kerja.

Website : http://iournal.unismuh.ac.id/index.php/kolaborasi 


\section{PENDAHULUAN}

Negara Indonesia adalah negara yang sedang berkembang dengan keanekaragaman suku, agama, ras, dan budaya, pada satu sisi hal ini merupakan suatu kekayaan yang bias menjadi potensi bangsa bila dikelola dengan baik. Namun pada sisi lainnya hal ini bias memberi dampak buruk bagi kehidupan social masyarakatnya bila pemerintah tidak bisa mengolah potensi suatu bangsa maka dapat mengakibatkan ketimpangan, ketidakadilan dan kesenjangan sosial.

Menurut Midgley (2005) Selain menfasilitasi dan mengarahkan pembangunan sosial, pemerintah juga seharusnya memberikan kontribusi langsung pada pembangunan social lewat bermacam kebijakan dan program sector publik. Salah satu contohnya dalam penyediaan lapangan kerja, dengan banyaknya jumlah penduduk Indonesia tentu harus seimbang dengan penyediaan lapangan kerja. Dalam hal ini dibutuhkan kerjasama antara pemerintah dan swasta dalam penyediaan lapangan kerja bagi masyarakat disekitar. Pasal
27 Ayat (2) Undang-Undang Dasar Tahun 1945 meyebutkan bahwa "setiap warga Negara berhak atas pekerjaan dan penghidupan yang layak bagi manusia".

Salah satu mata pencaharian masyarakat Indonesia adalah berada pada sector tambang, dengan kekayaan alam Indonesia dari batu bara ,minyak, gas bumi dan mineral menjadikan sector tambang sebagai salah satu roda penggerak perekonomian Indonesia untuk meningkatkan kesejaheraan rakyat oleh karena itu, pemanfaatan dan pengelolaannya harus memberi nilai tambah bagi perekonomian nasional. Terkait hal tersebut pemerintah terus menerus melakukan upaya-upaya untuk mendorong para pelaku usaha agar terus berbenah diri dan melakukan pembaharuan dan inovasi sehingga sector tambang dan mineral dapat mendongkrak nilai tambah tambang dan mineral Indonesia keposisi yang dapat mensejahterakan rakyat.

Dalam hal ini upaya pemerintah tersebut tertuang melalui UndangUndang No.4 Tahun 2009 tentang 
pertambangan mineral dan batubara (Minerba), dimana materi pokok yang terkandung dalam undang-undang tersebut mengatur penghiliran hasil tambang hasil tambang mineral dan batubara dan melarang ekspor bahan mentah hingga tahun 2014, pada pasal 102 menyatakan bahwa "pemegang IUP dan IUPK wajib meningkatkan nilai tambah sumber daya mineral dan/atau batubara dalam pelaksanaan penambangan, pengolahan dan pemurnian, serta pemanfaatan mineral dan batubara" dan pada pasal 103 ayat (1) “ pemegang IUP dan IUPK operasi produksi wajib melakukan pengolahan dan pemurnian hasil penambangan di dalam negeri”.

Dikeluarkannya aturan larangan ekspor raw materials atau ekspor bahan mentah yang terhitung sejak 12 Januari 2014 yang tujuannya untuk menaikkan dan meningkatkan devisa Negara dan nilai tambah berupa nilai ekonomi dan menciptakan lapangan kerja namun kebijakan pemerintah tersebut berbanding terbalik dengan tujuan dari Undang-Undang No.4 Tahun 2009, justru membuat tenaga kerja yang tercipta menjadi PHK missal karena aturan tersebut berdampak merugi pada perusahaanperusahaan yang bergelut dengan ekspor bahan mentah.

Salah satu perusahaan yang terkena imbas dan merugi adalah perusahaan marmer yang ada di Kabupaten Pangkep, PT Gunung Mas Persada Jaya yang terletak di Desa Bara Batu, jln A.Mappe melakukan pemutusan hubungan kerja (PHK) terhadap 105 karyawannya dari total 283 karyawannya yang terdiri dari 275 laki-laki dan 8 orang perempuan karena produksi yang semakin melesu, berkurangnya pendapatan perusahaan tentu akan berdampak pada kesejahteraan karyawan hal inilah yang mengakibatkan dirumahkannya hingga di PHK-nya ratusan karyawan karena perusahaan tak sanggup lagi membayar gaji karyawan. (Edy Widodo, PT Gunung Mas Persada Jaya)

Ermaya Suradinata (Zaidan Nawawi, 2013:18) mendefinisikan pemerintah sebagai lembaga atau badan-badan public yang mempunyai 
fungsi melakukan upaya untuk mencapai tujuan Negara.

Apter (Ndraha, 2001: 71) pemerintah adalah sekelompok orang yang bertanggung jawab atas penggunaan kekuasaan (exersicing power). sedangkan Osborne dan Plastrik (Delly Mustafa, 2013 : 76) menejelaskan bahwa pemerintah merupakan lembaga yang besar, kompleks, dan ruwet.

Pemutusan hubungan kerja akan mengakibatkan konflik antara pekerja dan perusahaan apabila permasalahan pemutusan hubungan kerja tidak diselesaikan dengan kata sepakat dari kedua belah pihak. Pemberhentian harus berprikemanusiaan dan menghargai pengabdian yang diberikan kepada perusahaan dengan cara memberi uang pesangon atau pensiun, dan perusahaan dapat digugat ke pengadilan Tata Usaha Negara (PTUN) bila PHK tidak tepat.Peran pemerintah yang dimaksud oleh (Arief, 2012) dalam pembinaan masyarakat antara lain : 1) Pemerintah sebagai regulator yaitu Peran pemerintah sebagai regulator adalah menyiapkan arah untuk menyeimbangkan penyelenggaraan pembangunan melalui penerbitan peraturan-peraturan. Sebagai regulator, pemerintah memberikan acuan dasar kepada masyarakat sebagai instrumen untuk mengatur segala kegiatan pelaksanaan pemberdayaan. 2) Peran pemerintah sebagai dinamisator adalah menggerakkan partisipasi masyarakat jika terjadi kendala-kendala dalam proses pembangunan untuk mendorong dan memelihara dinamika pembangunan daerah. Pemerintah berperan melalui pemberian bimbingan dan pengarahan secara intensif dan efektif kepada masyarakat. Biasanya pemberian bimbingan diwujudkan melalui tim penyuluh maupun badan tertentu untuk memberikan pelatihan. 3) Peran pemerintah sebagai fasilitator adalah menciptakan kondisi yang kondusif bagi pelaksanaan pembangunan untuk menjembatani berbagai kepentingan masyarakat dalam mengoptimalkan pembangunan daerah. Sebagai fasilitator, pemerintah bergerak di bidang pendampingan melalui 
pelatihan, pendidikan, dan peningkatan keterampilan, serta di bidang pendanaan atau permodalan melalui pemberian bantuan modal kepada masyarakat yang diberdayakan.

Menurut sembiring (2012: 8) fungsi pemerintah negara termasuk pemerintah daerah dimanapun berada, sekurang-kurangnya melakukan fungsi pelayanan (services), fungsi pengaturan (regulation), fungsi pemberdayaan (empowering), dalam upaya mewujudkan tata kelola pemerintahan yang baik (good governance).

Menurut De Dreu dan Gelfand (Dewi hanggraeni: 2011) menyatakan bahwa konflik sebagai suatu proses yang terjadi ketika individu atau kelompok menyadari perbedaan dan pertentangan di antara dirinya dan individu atau kelompok lain terkait dengan kepentingan dan sumberdaya, keyakinan, nilai, tindakan dan sebagainya.

Robbins (Sopiah: 2008) Konflik adalah suatu proses yang dimulai bila satu pihak merasakan bahwa pihak lain telah mempengaruhi secara negatif atau akan segera memengaruhi secara negatif pihak lain. Sedangkan Alabaness mengartikan konflik sebagai kondisi yang dipersepsikan ada diantara pihak-pihak atau lebih merasakan adanya ketidak sesuaian antara tujuan dan peluang untuk mencampuri usaha pencapaian tujuan pihak lain. Imam Soepomo (Agusmidah, 2010 : 43) menyatakan bahwa hubungan kerja terjadi setelah adanya perjanjian kerja antara buruh dan majikan, yaitu suatu perjanjian dimana pihak kesatu buruh, mengikat diri untuk bekerja dengan menerima upah pada pihak lainnya, majikan yang mengikat diri untuk mempekerjakan buruh itu dengan membayar upah pada pihak lainnya. Pemberhentian adalah fungsi operatif terakhir manajemen sumber daya manusia. Istilah pemberhentian sinonim dengan separation, pemisah atau pemutusan hubungan kerja (PHK).

Pemutusan hubungan kerja adalah pengakhiran hubungan kerja antara pengusaha dan pekerja bedasarkan ijin panitia daerah atau panitia pusat. Istilah pemutusan hubungan kerja 
(PHK) (sparation) memiliki kesamaan dengan pemberhentian atau pemisahan karyawan dari suatu organisasi. Malayu S.P. Hasibuan pemberhentian adalah pemutusan hubungan kerja seseorang karyawan dengan suatu organisasi perusahaan. Dengan pemberhentiannya, berarti berakhirnya keterikatan kerja karyawan terhadap perusahaan.

Tulus (1993), pemutusan hubungan kerja (separation) adalah mengembalikan karyawan ke masyarakat. Pemutusan hubungan kerja dalam (Suwatno dan Donni juni, 2011) dikemukakan bahwa pemutusan hubungan kerja dapat terjadi karena adanya beberapa alasan, yaitu : 1) Undang-Undang dapat menyebabkan seorang karyawan harus diberhentikan dari suatu perusahaan, misalnya karyawan anak-anak, karyawan WNA, atau karyawan yang terlibat organisasi terlarang. 2) Keinginan perusahaan antara lain: Karyawan tidak mampu menyelesaikan pekerjaannya, Perilaku dan disiplinnya kurang baik, Melanggar peraturan-peraturan dan tata tertib perusahaan, Tidak dapat bekerja sama dan terjadi konflik dengan karyawan lain, Melakukan tindakan amoral dalam perusahaan. 3) Keinginan karyawan, Pemberhentian atas keinginan karyawan sendiri dengan mengajukan permohonan untuk berhenti dari perusahaan tersebut. 4) Pensiun, Undang-undang mempensiunkan seseorang karena telah mencapai batas usia dan masa kerja tertentu. Usia kerja seorang karyawan untuk berstatus kepegawaian adalah 55 tahun atau seseorang dapat dikenakan pensiun dini, apabila menurut keterangan dokter, karyawan tersebut sudah tidak dapat mampu lagi untuk bekerja dan umurnya sudah mencapai 50 tahun dengan masa pengalaman kerja minimal 15 tahun. 5) Kontrak kerja berakhir, Beberapa perusahaan sekarang ini banyak mengadakan perjanjian kerja dengan karyawannya didalam suatu kontrak dimana didalamnya disebutkan masa waktu kerja atau masa kontraknya. 6) Meninggal dunia. 7) Perusahaan dilikudasi, masalah pemberhentian karyawan diatur dengan peraturan perusahaan, perjanjian bersama dan 
peraturan perundang-undangan yang berlaku. Untuk menentukan apakah benar atau tidak perusahaan dilikudasi atau dinyatakan bangkrut harus didasarkan kepada peraturan perundang-undangan.

\section{METODE PENELITIAN}

Penelitian ini dilaksanakan kurang lebih 2 bulan, Penelitian ini berlokasi di kantor Dinas Ketenagakerjaan Kabupaten Pangkep, jenis penelitian yang digunakan dalam penelitian ini adalah deskriptif kualitatif dengan tipe penelitian fenomenology.

Sumber data yang didapatkan peneliti berasal dari dua sumber yakni data primer yang diperoleh peneliti melalui hasil observasi dan wawancara oleh lima orang informan dan data sekunder yaitu data yang dikumpulkan peneliti dari dokumen-dokumen dan laporan-laporan yang bersifat informasi yang digunakan dalam penelitian.

Teknik analisis data yang digunakan dalam penelitian ini adalah menggunakan tiga macam kegiatan analisis yaitu reduksi data merangkum dan memilah data yang diperlukan hingga mempermudah peneliti untuk pengumpulan data selanjutnya, Model (Display data) yaitu dengan menyajikan data bersifat dan terkadang juga data disajikan dalam bentuk bagan, grafik, matriks dan lainlainnya. Penarikan/Verifikasi kesimpulan yaitu menarik kesimpulan pada gambaran dari suatu objek yang sebelumnya masih belum jelas, sehingga setelah diteliti menjadi lebih jelas.

Informan dalam penelitian ini adalah sebanyak delapan orang yang terdiri dari Sekertaris Dinas Ketenagakerjaan Kabupaten Pangkep dan Seksi persyaratan kerja dari Dinas Ketenagakerjaan Kabupaten Pangkep, Serikat Pekerja/Buruh, Bendahara PT Gunung Mas Persada Jaya dan Karyawan yang terkena PHK. Dan dalam menganalisis data peneliti menggunakan tiga triangulasi yaitu triangulasi sumber, triangulasi waktu dan triangulasi teknik. Triangulasi adalah teknik pemeriksaan keabsahan data yang memanfaatkan sesuatu yang 
lain dalam membandingkan hasil wawancara terhadap objek penelitian.

\section{HASIL DAN PEMBAHASAN}

Berdasarkan dengan tujuan penelitian ini yang tercantum pada bab sebelumnya, yaitu untuk mengetahui bagaimana peran pemerintah dalam menangani konflik pemutusan hubungan kerja karyawan PT Gunung Mas Persada Jaya di Kabupaten Pangkep dan apa saja yang menjadi faktor penghambat dan pendukung pemerintah dalam menjalankan peranannya. Adapun indikator dalam penelitian ini adalah peran pemerintah sebagai regulator, fasilitator dan dinamisator.

Pemutusan hubungan kerja (PHK) merupakan hal yang sensitive karena berhubungan langsung dengan mata pencaharian, selain dapat menurunkan tingkat kesejahteraan masyarakat juga akan menimbulkan pengangguran dan lebih rumit lagi apabila pemutusan hubungan kerja yang menyisakan konflik antara perusahaan dan karyawan yang berujung demonstrasi besar-besaran. Sudah dipastikan bahwa pemutusan hubungan kerja akan menimbulkan efek domino atau multiplier efek yang saling berkaitan, telah menjadi tanggung jawab pemerintah sebagai pemegang amanah dan sebagai pelayan masyarakat untuk mengetahui serta berupaya menyelesaikan dan menangani konflik yang terjadi antara pihak pekerja dan perusahaan.

Pada tahun 2015 lalu pertambangan khususnya perusahaan marmer di Kabupaten Pangkep sedang mengalami masa-masa sulit karena adanya kebijakan Menteri ESDM terkait larangan ekspor raw materials (ekspor bahan mentah) aturan ini mengharuskan perusahaan melakukan pemurnian dan pengolahan didalam negeri sebelum melakukan ekspor keluar negeri. Salah satu perusahaan yang merasakan imbas dari kebijakan ini adalah PT Gunung Mas Persada Jaya yang mengalami penurunan pendapatan produksi dan terpaksa merumahkan hingga melakukan pemutusan hubungan kerja terhadap ratusan karyawannya karena perusahaan marmer ini lebih 
mengandalkan pasar luar negeri dibandingkan pasar dalam negeri.

Pemerintah dalam hal ini adalah Dinas Ketenagakerjaan Kabupaten Pangkep adalah wadah tempat berlindungnya buruh dan pekerja yang ada di Kabupaten Pangkep terkait dengan persoalan pemutusan hubungan kerja karyawan PT Gunung Mas Persada Jaya, dibutuhkan peranan pemerintah terutama dalam rangka menangani dan menyelesaikan konflik dari PHK dengan mengadakan beberapa tindakan untuk menciptakan suasana kondusif yang di akibatkan dari adanya pemutusan hubungan kerja.

Peran pemerintah sebagai regulator adalah menyiapkan arah untuk menyeimbangkan penyelenggaraan pembangunan melalui penerbitan peraturanperaturan. Sebagai regulator, pemerintah memberikan acuan dasar kepada masyarakat sebagai instrumen untuk mengatur dan menangani persoalan yang terjadi dari adanya pemutusan hubungan kerja. Dalam menangani konflik antara perusahaan dan karyawan yang diakibatkan dari adanya pemutusan hubungan kerja (PHK) pemerintah dalam hal ini Pemerintah dituntut mengeluarkan aturan ataupun kebijakan yang tujuannya untuk menghasilkan kesepakatan antara pihak pekerja dan perusahaan untuk menciptakan iklim yang kondusif. Perundingan Tripartit menjadi langkah yang ditempuh Dinas untuk mempertemukan, melakukan negosiasi dan perundingan antara Serikat pekerja dan perusahaan untuk mendapatkan kesepakatan bersama. . Tripartit berperan sebagai forum komunikasi dan musyawarah antara pekerja, pemerintah dan perusahaan untuk membahas tuntutan-tuntutan pekerja yang diputus hubungan kerjanya.

penyelesaian masalah PHK melalui pertemuan Tri Partit antara pemerintah pengusaha/organisasi dan serikat pekerja sebagai perwakilan dari pekerja yang artinya Tripartit sebagai perumus dalam memecahkan masalah. Dalam Undang-Undang PPHI No.2 Tahun 2004 pasal 1 angka 10 disebutkan dalam penyelesaian 
perselisihan hubungan industrial melalui perundingan Bipartit dan perundingan Tripartit keduanya bertujuan untuk menyelesaikan perselisihan hubungan kerja atau hubungan industrial antara pengusaha/perusahaan/pemberi kerja dengan pekerja/buruh. Perundingan Bipartit perundingan antara pekerja/buruh atau serikat pekerja/serikat buruh dengan pengusaha untuk menyelesaikan perselisihan hubungan industrial. Sedangkan perundingan Tripartit adalah penyelesaian perselisihan hubungan industrial melalui pihak ketiga.

$$
\text { Sebelumnya penyelesaian }
$$
melalui perundingan Bipartit lebih dulu namun dalam perundingan itu tidak ditemui kesepakatan hingga dilaksanakanlah perundingan Tri partit yang oleh Dinas Ketenagakerjaan Kabupaten Pangkep telah dipertemukan tiga unsur penting yaitu pemerintah, pengusaha dan serikat pekerja serta untuk menyelesaikan masalah pemutusan hubungan kerja oleh PT Gunung Mas Persada Jaya dan menyelesaikan persoalan tuntutan oleh karyawan yang di PHK dengan melalui perundingan dan negosiasi namun, penentuan dan pembayaran uang pesangon pekerja tidak sesuai dengan undang-undang, pembayaran hanya mengacu pada UMK bukan pada gaji pokok yang tentunya membuat pekerja merasa dirugikan oleh pihak perusahaan.

Hasil dari Tri Partit tersebut kompensasi yang diterima oleh pekerja tidak sesuai dengan UUD yakni hanya $1 \mathrm{X}$ ketentuan itupun hanya mengacu pada umk bukan pada gaji pokok (1XUmk X Masa kerja X 15\%) dan jamsostek yang seharusnya adalah $2 X$ ketentuan yaitu ( $2 \mathrm{X}$ Gaji pokok $\mathrm{X}$ Masa kerja X 15\%). Hal ini bisa saja diperselisihkan ke ranah PHI (Pengadilan Hubungan Industrial) namun posisi pekerja hanya akan semakin melemah karena untuk ke pengadilan membutuhkan biaya dan waktu yang tidak sedikit setidaknya 2 tahun terlebih lagi jika sampai ke ranah MK maka pihak buruh harus menyewa seorang pengacara berlisensi tentu hal ini akan melemahkan pihak 
pekerja dan menguntungkan pihak pengusaha yang memliki kekuatan (Modal). karyawan yang di PHK menyatakan bahwa mereka sangat berharap kepada Dinas Ketenagakerjaan untuk diselesaikan perselisihan hak karyawan seperti pesangon dan uang tunjangan diselesaikan sesuai dengan Undangundang yang berlaku tanpa merugikan pihak pekerja.

Masyarakat pada umumnya memiliki keterbatasan dalam mengembangkan dirinya. Oleh karena itu diperlukan pendamping untuk membimbing dalam upaya memperbaiki kesejahteraan masyarakat, dimana pendampingan meliputi upaya peningkatan kualitas sumber daya manusia dan sebagai solusi yang ditawarkan pemerintah. Pembinaan yang dilakukan oleh Dinas Ketenagakerjaan untuk karyawan yang diPHK bisa dikatakan masih sangat kurang serta tidak adanya bimbingan dan pengarahan khusus yang diberikan dari Dinas untuk karyawan yang terkena PHK. Karyawan yang diPHK memiliki keterbatasan untuk mengajukan tuntutan-tuntutan yang dirasa kurang adil bagi pekerja, selain dengan mengandalkan Serikat Pekerja, juga diperlukan pendamping untuk membimbing dalam upaya menangani konflik yang terjadi akibat dari adanya pemutusan hubungan kerja karyawan, dimana pendampingan meliputi di bentuknya suatu tim sebagai solusi yang ditawarkan pemerintah.

Upaya yang dilakukan oleh Pemerintah sebagai dinamisator dalam menangani konflik antara pekeja yang diPHK dan perusahaan yaitu dengan membentuk LKS Triparti (Lembaga Kerjasama Tripartit). LKS Tripartit (Lembaga kerjasama Tripartit) yaitu sebuah forum komunikasi, konsultasi dan musyawarah guna memberikan pertimbangan, saran dan pendapat kepada pemerintah terkait penyusunan kebijakan dan pemecahan masalah ketenagakerjaan.

Dinas Ketenagakerjaan sebagai Dinamisator dalam menangani konflik pemutusan hubungan kerja karyawan PT Gunung Mas Persada Jaya di kabupaten Pangkep telah terealisasi, dengan membentuk suatu tim, sesuai 
dengan Undang-undang Ketenagakerjaan No.13 Tahun 2003 pasal 107 ayat 3 yaitu keanggotaan LKS Tripartit terdiri dari unsur pemerintah, organisasi pengusaha dan serikat pekerja/buruh.

\begin{tabular}{cll} 
Dinas & \multicolumn{2}{l}{ Ketenagakerjaan telah } \\
membentuk & suatu tim yaitu & LKS
\end{tabular} Tripartit (Lembaga kerjasama Tripartit) yaitu sebuah forum komunikasi, konsultasi dan musyawarah guna memberikan pertimbangan, saran dan pendapat kepada pemerintah terkait penyusunan kebijakan dan pemecahan masalah ketenagakerjaan.

LKS Tripartit Kabupaten Pangkep Ketuai oleh Bupati Kabupaten Pangkep, diwakili oleh Kepala Dinas Ketenagakerjaan dan sekertaris oleh Kepala Bidang Hubungan Indusrial, lima orang anggota Serikat pekerja dan Buruh.

Tugas dari lembaga kerjasama Tripartit yaitu menggalang komunikasi dan kerjasama yang baik antara pemerintah, pekerja dan pengusaha, dan menampung, merumuskan serta memecahkan masalah-masalah yang menyangkut kepentingan bersama. memecahkan masalah-masalah bersama dalam bidang ketenagakerjaan.

Unsur kerja Tripartit yaitu menampung, mengkaji, mengevaluasi dan merumuskan rancangan kebijakan dan memecahkan masalah ketenagakerjaan yang bersifat regional daerah dan sektoral sebagai saran kepada pemerintah dan pihak-pihak terkait, menggalang komunikasi dan kerjasama timbal balik yang sebaikbaiknya dengan unsure tripartit, melakukan koordinasi dengan instansi atau dengan lembaga lainnya yang beranggotakan unsur tripartit.

Peran pemerintah sebagai fasilitator adalah menciptakan kondisi yang kondusif bagi pelaksanaan pembangunan untuk menjembatani berbagai kepentingan masyarakat dalam mengoptimalkan kinerja pemerintah bergerak di bidang pendampingan melalui pelatihan, pendidikan, dan peningkatan keterampilan, serta di bidang pendanaan atau bantuan melalui pemberian bantuan sarana dan 
prasarana kepada masyarakat setempat.

Dalam penyelesaiaan pemutusan hubungan kerja Dinas Ketenagakerjaan berperan sebagai fasilitator yaitu untuk menemukan dan menyelesaikan masalah, membantu beberapa pihak dalam mengambil keputusan dan mencapai kesepakatan dalam hasil pertemuan.

Dinas Ketenagakerjaan berperan sebagai fasilitator yaitu untuk menemukan dan menyelesaikan masalah, membantu beberapa pihak dalam mengambil keputusan dan mencapai kesepakatan dalam hasil pertemuan. Dinas ketenagakerjaan dalam upaya menyelesaikan konflik antara pekerja dan perusahaan yaitu dengan cara mendatangkan seorang mediator, dalam Undang-Undang No.2 Tahun 2004 tentang penyelesaian perselisihan hubungan industrial dikatakan bahwa mediator penyelesaian hak, penyelesaian kepentingan dan perselisihan hubungan kerja diselesaikan dengan musyawarah yang ditengahi oleh seorang mediator, mediator bertugas melakukan mediasi dan mempunyai kewajiban anjuran tertulis kepada para pihak yang berselisih. Dinas Ketenagakerjaan memfasilitasi pekerja dengan mengadakan pertemuan dengan pihak perusahaan. Dinas sebagai pihak ketiga bekerja sebagai penengah antara perusahaan dan karyawan untuk mempermudah penyelesaian perselisihan hak-hak kepentingan karyawan.

Dinas Ketenagakerjan Kabupaten Pangkep dalam menangani konflik pemutusan hubungan kerja karyawan PT Gunung Mas Persada Jaya dapat disimpulkan bahwa Dinas Ketenagakerjaan telah menjembatani dan memfasilitasi kepentingankepentingan karyawan yang telah di PHK dengan menyurati pihak perusahaan kemudian mempertemukan dan mengadakan mediasi antara perusahaan dan karyawan yang di PHK yang diwakili oleh serikat pekerja dan juga menyediakan mediator untuk memediatori pada perundingan Tripartit sehingga persoalan pemutusan hubungan kerja bisa diselesaikan secara musyawarah 
(Tahap Tripartit) dan menemui kata sepakat tanpa menempuh Pengadilan Penyelesaian Hubungan Industrial (PPHI).

\section{Faktor pendukung pemerintah dalam menjalankan peranannya ialah:}

LKS Tripartit (Lembaga Kerja Sama Tripatrit adalah salah satu menjadi faktor pendukung pemerintah dalam menyelesaikan perselisihan hubungan kerja yang terjadi antara karyawan yang diPHK dan pihak perusahaan. Unsur kerja LKS Tripartit adalah menampung, mengkaji, mengevaluasi dan merumuskan rancangan kebijakan dan memecahkan masalah ketenagakerjaan yang bersifat regional, daerah dan sektoral sebagai saran kepada pemerintah dan pihakpihak terkait, menggalang komunikasi dan kerjasama timbal balik yang sebaik-baiknya dengan Tripartit, melakukan koordinasi dengan instansi atau lembaga lainnya yang beranggotakan unsur Tripartit. dan adanya wewenang dari pemerintah dan kepercayaan yang diberikan dari serikat pekerja dan perusahaan untuk
Dinas Ketenagakerjaan dalam menyelesaikan masalah PHK yang terjadi di PT Gunung Mas Persada Jaya, sehingga Dinas dapat berperan penting dalam penyelesaian konflik antara karyawan yang diPHK dan perusahaan.

Faktor penghambat pemerintah dalam menjalankan peranannya ialah:

Dalam menyelesaikan perselisihan antara karyawan PHK dan PT Gunung Mas Persada Jaya, Dinas Ketenagakerjaan telah mengadakan pertemuan yang selanjutnya dilakukan Mediasi yang ditengahi oleh mediator.Tidak adanya mediator adalah menjadi kekurangan Dinas Ketenagakerjaan Kabupaten Pangkep, sehingga untuk menyelesaikan masalah pemutusan hubungan kerja dan konflik antara pekerja dan perusahaan dimediasi oleh mediator yang didatangkan dari Kabupaten Maros. Dinas Ketenagakerjaan masih membutuhkan pelatihan dan bimbingan teknis hingga pegawai dapat mengembangkan diri dan mampu memahami seluk-beluk 
pelaksanaan pekerjaan lebih mendalam dan dapat meningkatkan kompetensi dan kinerja pegawai. Peran pemerintah dalam menangani konflik pemutusan hubungan kerja karyawan PT Gunung Mas Persada Jaya masih terkendala dengan kurang baiknya hubungan/komunikasi yang terjalin antara pihak perusahaan dan pemerintah dalam menyelesaikan persoalan perselisihan hubungan industri terutama PHK yang terjadi.

\section{KESIMPULAN}

Setelah melalui beberapa proses penelitian kualitatif yang telah diterapkan dan diuraikan pada bab-bab sebelumnya maka penulis dapat menyimpulkan sebagai berikut : 1) Peran pemerintah dalam menangani konflik pemutusan hubungan kerja karyawan PT Gunung Mas Persada Jaya yaitu Dinas Ketenagakerjaan Kabupaten Pangkep memiliki peran sebagai fungsi a) Regulator yaitu berdasarkan pada Undang-undang No.2 Tahun 2004 tentang Penyelesaian perselisihan Hubungan kerja dalam hal ini melalui perundingan Tripartit, b)
Dinamisator yaitu membentuk suatu Lembaga Kerjasama (LKS Tripartit) yang di keanggotaannya berisikan tiga unsure penting yaitu pemerintah, serikat pekerja dan organisasi pengusaha untuk menyelesaikan konflik antara kedua belah pihak yang memiliki kepentingan, c) Fasilitator dalam hal ini pemerintah setempat menyediakan sarana seperti menghadirkan mediator untuk memediasi perundingan hak-hak dan kepentingan kedua belah pihak. 2) Beberapa faktor penghambat pemerintah dalam menangani konflik pemutusan hubungan kerja karyawan PT Gunung Mas Persada Jaya yaitu : Kabupaten Pangkep sendiri tidak memiliki mediator sehingga mediator didatangkan dari Kabupaten Maros, kurangnya komunikasi dengan pihak perusahaan dan kurangnya pelatihan dan bimbingan teknis. Sedangkan beberapa faktor pendukung pemerintah dalam menangani konflik pemutusan hubungan kerja karyawan PT Gunung Mas Persada Jaya di Kabupaten Pangkep yaitu : adanya kepercayaan dan kewenangan yang diberikan oleh 
beberapa pihak dalam menyelesaikan persoalan pemutusan hubungan kerja karyawan PT Gunung Mas Persada Jaya dan adanya LK Bipartit dan Tripartit yang memudahkan dalammenyelesaikan perselisihan kedua belah pihak.

\section{DAFTAR PUSTAKA}

Agusmidah, 2010. Hukum ketenagakerjaan indonesia, Medan:Ghalia

Anggraeni,Dewi, 2011.Perilaku Organisasi, Jakarta:Lembaga Penerbit Fakultas Ekonomi Universitas Indonesia.

Ariefgii. 2012. Peran Pemerintah Dalam Pemberdayaan.

Hasibuan.S.P,Malayu, 2014. Manajemen sumberdaya manusia, Jakarta: PT Bumi Aksara.

Mustafa,Delly, 2013. Brokrasi pemerintahan, Bandung: Alfabeta.

Nawawi,Zaidan,2013. Manajemen Pemerintahan,Jakarta: Raja grafindo persada.

Ndraha,Taliziduhu, 2011. Kybernology ilmu pemerintahan baru, Jakarta: PT Rineka cipta.

Sembiring,Masana.2012. Budaya dan Kinerja Organisasi,Bandung:Fokus Media.

Suwatno dan Juni donni, 2011. Manajemen SDM dalam organisasi public dan bisnis, Bandung: Alfabeta Sopiah, 2008. Perilaku Organisasional, Yogyakarta: $\mathrm{Cv}$ Andi 